\title{
Determinant of Development Strategies and Leadership Styles on Organizational Commitment and Their Implications for MSMEs Performance in Palembang
}

\author{
Darul Amri ${ }^{1 *}$, M. Thoyib ${ }^{1}$, Frimansyah ${ }^{1}$, Riza Wahyudi ${ }^{1}$ \\ ${ }^{I}$ Department of Accounting, Politeknik Negeri Sriwijaya, Palembang, Indonesia \\ *Corresponding author. Email: darulamri2005@gmail.com
}

\begin{abstract}
This study aims to analyse the determinants of the development strategy and leadership style on organizational commitment and its implications on the performance of micro, small and medium enterprises (MSMEs) in Palembang. The samples were taken using non-random sampling technique, namely purposive sampling technique; consist of 120 respondents from 252 MSMEs fostered by Palembang Office of Cooperatives and Small and Medium Enterprises. The research unit is entrepreneurs (managers) of MSMEs and the hypotheses are tested using the Structure Equation Model (SEM) with the Lisrel program. The results of the study show that the R-squared for structural equation I is $20 \%$ with error var of $80 \%$ while the Rsquared for structural equation II is $64 \%$ with the error of $36 \%$. The results also present that development strategy and leadership style, have a positive and significant effect on organizational commitment simultaneously. It is also found that, simultaneously, the development strategy, leadership style and organizational commitment have a positive and significant effect on the performance of micro, small and medium businesses. However, when tested partially, only development strategy has no significant effect on organizational commitment. Therefore, it can be said that organizational commitment is not act as a full mediator on the model.
\end{abstract}

Keywords: development strategies, leadership style, organizational commitment, organizational performance

\section{INTRODUCTION}

The main strategy undertaken by the government in supporting economic development is to empower and grow Micro, Small and Medium Enterprises (MSMEs) as a basis for popular economic development. Experience has shown that MSMEs in Indonesia still exist and develop despite the economic crisis. But in other parts, MSMEs also face many problems, namely limited working capital, low quality of Human Resources, and lack of mastery of science and technology. Other problems faced by MSMEs are the connection with the lack of clarity about business prospects and planning, and the lack of vision and mission. This happens because generally MSMEs are only aimed at increasing income or capital.

These characteristics can be seen in micro, small and medium businesses today, in general MSMEs are familyowned businesses, the use of technology is still relatively simple, lacks access to capital (bankable), and there is no separation of business capital from personal needs.

Efforts to increase economic development in rural and urban areas especially to spur the improvement in the Micro, Small and Medium Enterprises Development Strategy in strengthening community economy, community income, cooperatives is one of the alternatives to empower the community's economy. In order for MSMEs and cooperatives to grow and develop, supporting factors must also be developed. The results from field observations found several factors that can support regional economic development through cooperative development, according to the criteria stated by [1], such as, 1) community potential; 2) businessman; 3) credit institutions; 4) related institutions; and 5) cooperatives as business entity. Therefore, business players should have a strategy in overcoming the problems of MSMEs.

Another factor that is not less important is the leadership style that belongs to the entrepreneurship that must grow in accordance with the growth of businesses that dare to take high-risk actions, among others, making innovative breakthroughs and creative thinking for their businesses.

The next factor is that MSMEs also need the behavior of their leaders and employees to generate business (organizational) commitment that is continuously fostered so that the business activities undertaken become a total movement within the organization. Commitment behavior must be embedded in every individual in the organization. This is often forgotten by businesses at the MSME level. After gathering various strategic issues, it is necessary to pay attention to the development of MSMEs in order to achieve optimal organizational performance. Other strategic issues in the form of leadership styles, 
organizational commitment, performance improvement through increased competitiveness and market expansion. Based on the description above, it is necessary to examine the issues of the Development Strategy and Leadership Style on Organizational Commitment and its implications for MSME Performance in Palembang, South Sumatra.

\section{LITERATURE REVIEW}

\subsection{MSMEs Development Strategy}

Strategy is the way a company's business leader realizes his philosophy. This understanding emphasizes the strategy should be related to large decisions faced by individuals or organizations in doing business which determines the failure and success of individuals or organizations. According to [2], strategy defines as a tool to achieve long-term goals. In addition the strategy is also interpreted as a potential action that requires top-level management decisions and company resources in large numbers [3].

In general, the strategy is a comprehensive approach related to the implementation of ideas, planning, and implementation of an activity within a certain period. A good strategy requires more coordination of the teamwork, able to identify supporting factors that are in accordance with the principles of implementing ideas rationally, efficient in funding, and has tactics to achieve goals effectively. Strategy is also a broad set of organizational plans for implementing decisions taken to achieve organizational goals. The strategy into three groups that can be considered to be applied in a company, namely: (1) corporate strategy (corporate strategy), (2) business strategy or competitive strategy, and (3) functional strategy [4].

Development can be interpreted as an effort to improve the conceptual, theoretical, technical, and moral abilities of individuals in accordance with the needs of work or position through education and training. Stating that the development of SMEs is more directed to become a competitive economic actor through strengthening entrepreneurship and increasing productivity supported by efforts to increase adaptation to market needs, the use of innovation and the application of technology. [5]

The development of MSMEs is essentially a shared responsibility between the government and the community. By looking at the problems faced by MSMEs, efforts are needed such as: Creating a conducive business climate, (b) Capital Aid, (c) Business Protection, (d) Partnership Development, (e) Training, (f) Developing Promotion, and (g) Developing equal cooperation. [6]

Based on the above theories, it can be synthesized that development strategy is a potential action of top management to strengthen competitiveness through strengthening entrepreneurship and productivity in efforts to adapt markets, as well as utilize innovation and technology with 2 dimensions; 1. Strengthening entrepreneurship with indicators, such as; concepts \& theories, technical, work morale, improvement of education, training, 2. Dimensions of increasing productivity with indicators, such as; adaptation to competitors, utilization of innovation results, use of the latest technology.

\subsection{Leadership Style}

According to [7] style means attitude, movement, behaviour, beautiful attitude, good gestures, strength, ability to do good. The full meaning of leadership style is behaviour and strategy, as a result of a combination of philosophy, skill traits, attitudes, which are often applied by leaders when trying to influence the performance of their subordinates. Leadership styles are a combination of the nature that used by leaders to influence their subordinates to roach organizational goal or can be said that leadership styles are pattern of behaviour strategy often implemented by a leader. [8]

Ohio State University distinguishes leader behaviour in initiating structure behaviour leadership styles (focusing on making tasks completed). Leaders define and structure their own roles and the role of subordinates towards the achievement of tasks, including assigning tasks to subordinates, maintaining certain performance standards, asking subordinates to follow standard procedures, emphasizing the importance of meeting deadlines, criticizing poor performance, and coordinating the activities of different subordinates. Meanwhile, in consideration of behaviour (focus on meeting people's needs and developing relationships), leaders act in a friendly, supportive manner and show attention to the needs and feelings of followers [9]

Based on the concepts and theories above, it can be synthesized that leadership style is a combination of traits and skills that is used when interacting with followers with two dimensions, namely initiating behaviour and consideration behaviour along with several indicators of both dimensions.

\subsection{Organizational Commitment}

Organizational commitment continues to be one of the most popular research themes studied because it has a significant influence on organizational performance, employee turnover, and employee / organizational performance [10], [11] defines organizational commitment as a positive evaluation of the organization and organizational goals. According to [12] organizational commitment is defined as commitment or bond between employees (individuals) and organizations (employers). In the term [13] organizational commitment is defined as his attachment in carrying out his work. In the terminology of organizational commitment is defined as the level of individuals in identifying their involvement in doing work, whereas according to [14] organizational commitment 
implies an understanding of the attachment and the power of individual identification of a job to achieve certain goals.

\subsection{Organizational Performance}

Performance according to [15], is the result achieved by someone in carrying out a job. With the importance of employee performance on work in the organization, the factors that influence employee performance are leadership style, and work motivation, employee commitment. In improving employee performance, organizational management needs to improve the quality of human resources, in order to get satisfactory work results.

\subsection{Previous research and hypothesis development}

Utomo [16] conducted a research on development strategy in MSMEs in Tarakan and found that MSMEs in Tarakan uses growth strategy by maintaining the quality of raw materials, legality/product permits, competitive prices and improving human resources. [17] also conducts similar research but yield different findings that MSMEs use strength strategy to overcome its threat. It is also suggested that MSMEs should diversify its product using technology such as CNC, CAD and CAM, improve product quality and build intensive partnership with suppliers. Furthermore, with regards to work commitment and organizational performance, Eka [18] found that motivation has a significant effect on organizational commitment and performance. Organizational commitment also has a significant effect on job performance. Moreover, the study also found out that job ability is insignificant on organizational commitment but positive on job performance.

Therefore, the hypothesis of this study is as follows:

H1: Development strategy, leadership style and organizational commitment have an effect on the performance of MSMEs both partially and simultaneously.

\section{METHODOLOGY}

\subsection{Data}

The population of this study is 252 MSMEs that are being fostered by Office of Cooperatives and Small Medium Enterprises. In selecting the sample, $25 \%$ of the total population are selected through purposive sampling in which each MSMEs 2 respondents are taken. The data are then taken using interview, questionnaires and observation.

\subsection{Variable Definition}

The variables used in this study are development strategy (X1), leadership style (X2), organizational commitment $(\mathrm{Y})$ and performance $(\mathrm{Z})$. In this study, likert scale is used to measure that reflects the interval scale.

\subsection{Data Analysis}

The data is then analyse using Structural Equation Model, with the following equations [19]:

Structure I: $Y=b_{1} X_{1}+b_{2} X_{2}+e i$

Structure II: $Z=Y+b_{1} X_{1}+b_{2} X_{2}+e i$

\section{RESULTS AND DISCUSSION}

\subsection{Structural Model Analysis}

Analysis of the data processing at the full model is done by testing the goodness of fit and statistical tests. The goodness of fit value of the model, the construction of development strategy, leadership style, organizational commitment, MSME performance can be seen in the table below.

Table 1 Results Goodness of Fit

\begin{tabular}{|c|l|c|c|c|}
\hline $\begin{array}{l}\mathrm{N} \\
\mathrm{o}\end{array}$ & $\begin{array}{l}\text { Goodness } \\
\text { of fit index }\end{array}$ & $\begin{array}{c}\text { Cutt off } \\
\text { Value }\end{array}$ & Results & Status \\
\hline 1 & $\begin{array}{l}\lambda^{2} \text { Chi } \\
\text { square }\end{array}$ & $\begin{array}{l}\text { Chi square }_{\text {hit }} \\
\text { Chi }_{\text {square }} \text { tabel }\end{array}$ & $\begin{array}{l}7002,55 \\
<0.0\end{array}$ & \\
\hline 2 & $\begin{array}{l}\text { Significant } \\
\text { probability }\end{array}$ & $\geq 0,05$ & 0,93 & $\begin{array}{c}\text { Good } \\
\text { Fit }\end{array}$ \\
\hline 3 & RMSEA & $\leq 0,08$ & 0,133 & $\begin{array}{c}\text { Good } \\
\text { Fit }\end{array}$ \\
\hline 4 & GFI & $\geq 0,90$ & 0,95 & $\begin{array}{c}\text { Good } \\
\text { Fit }\end{array}$ \\
\hline 5 & AGFI & $\leq 2,00$ & 0,96 & $\begin{array}{c}\text { Good } \\
\text { Fit }\end{array}$ \\
\hline 6 & CMIN/DF & $\geq 0,95$ & 1,02 & $\begin{array}{c}\text { Food } \\
\text { Fit }\end{array}$ \\
\hline 7 & TLI & $\geq 0,95$ & 0,96 & $\begin{array}{c}\text { Good } \\
\text { Fit }\end{array}$ \\
\hline 8 & CFI & & & \\
\hline
\end{tabular}

The table above identifies that the model formed has good goodness of fit, because it has values appropriate to the cut off value. RMSEA, CFI, TLI, NFI and IFI that meet the value of goodness of fit, so that the model obtained has a good goodness of fit.

Structural Equation - I: 
$\mathrm{Y}=0.17 * \mathrm{X} 1+0.31 * \mathrm{X} 2$, Errorvar. $=0.80, \mathrm{R}^{2}=0.20$

$$
\begin{array}{llr}
(0.12) & (0.12) & (0.11) \\
1.42 & 2.55 & 7.11
\end{array}
$$

Structural Equation - II:

$\mathrm{Z}=0.42 * \mathrm{Y}+0.26 * \mathrm{X} 1+0.30 * \mathrm{X} 2$, Error var. $=0.36, \mathrm{R}^{2}=$ 0.64

$\begin{array}{rlll}(0.085) & (0.092) & (0.095) & (0.11) \\ 4.93 & 2.85 & 3.17 & 3.36\end{array}$

\subsection{Hypothesis Testing}

Tests carried out on 2 (two) hypotheses simultaneously and 5 (seven) hypotheses partially. Simultaneous test is done using goodness of fit and F-test $=\mathrm{F}$ table 2.29, n 120 alpha $5 \%$ of the results of full model testing. Meanwhile, partial test is done using critical ratio $(\mathrm{CR})$ or $t$ value ( $\mathrm{t}$ test $=\mathrm{t}$ table 1.96) with a significance level of 0.05 .

\begin{tabular}{|c|c|c|c|c|c|}
\hline \multicolumn{2}{|c|}{$\begin{array}{l}\text { Structural } \\
\text { Equation }\end{array}$} & \multirow{2}{*}{$\begin{array}{c}\text { Path } \\
\text { Coeffic } \\
\text { ient } \\
\text { (Standa } \\
\text { rdize) }\end{array}$} & \multirow{2}{*}{$\begin{array}{l}\text { Std. } \\
\text { err } \\
\text { or }\end{array}$} & \multirow[t]{2}{*}{$\begin{array}{c}\mathrm{t}_{\text {coun }} \\
\mathrm{t}\end{array}$} & \multirow{2}{*}{$\begin{array}{c}\text { Results } \\
\text { of } \\
\text { t-table } \\
1.96 \\
\text { F- } \\
\text { table2,2 } \\
9 \\
\mathrm{n}=120 \\
\text { Alpha } \\
5 \%\end{array}$} \\
\hline $\begin{array}{c}\text { Latent } \\
\text { Variable } \\
\text { Endogen }\end{array}$ & $\begin{array}{c}\text { Latent } \\
\text { Variabl } \\
\mathrm{e} \\
\text { Eksoge } \\
n / \text { Endo } \\
\text { gen }\end{array}$ & & & & \\
\hline \multirow{3}{*}{$\begin{array}{c}\text { Organis } \\
\text { ational } \\
\text { Commit } \\
\text { ment }\end{array}$} & $\begin{array}{l}\text { Develo } \\
\text { pment } \\
\text { Strateg } \\
\text { y }\end{array}$ & 0,17 & $\begin{array}{c}0,1 \\
2\end{array}$ & $\begin{array}{c}1,4 \\
2\end{array}$ & $\begin{array}{c}\text { Positive } \\
\& \\
\text { insignifi } \\
\text { cant } \\
\text { (partial) }\end{array}$ \\
\hline & $\begin{array}{l}\text { Leader } \\
\text { ship } \\
\text { Style }\end{array}$ & 0,31 & $\begin{array}{c}0.1 \\
2\end{array}$ & $\begin{array}{c}2.5 \\
5\end{array}$ & $\begin{array}{c}\text { Positive } \\
\text { and } \\
\text { Significa } \\
\text { nt } \\
\text { (partial) }\end{array}$ \\
\hline & $\begin{array}{l}\text { Develo } \\
\text { pment } \\
\text { Strateg } \\
\text { y, } \\
\text { Leader } \\
\text { ship } \\
\text { Style }\end{array}$ & $\begin{array}{l}\mathrm{R} \\
\text { Square } \\
=20\end{array}$ & 80 & $\begin{array}{c}7,1 \\
1\end{array}$ & $\begin{array}{c}\text { Positive } \\
\& \\
\text { significa } \\
\text { nt } \\
\text { (simulta } \\
\text { neously) }\end{array}$ \\
\hline
\end{tabular}

Table 2 Results of goodness of fit struktural equation I
Table 3 Results of goodness of fit structural equation II

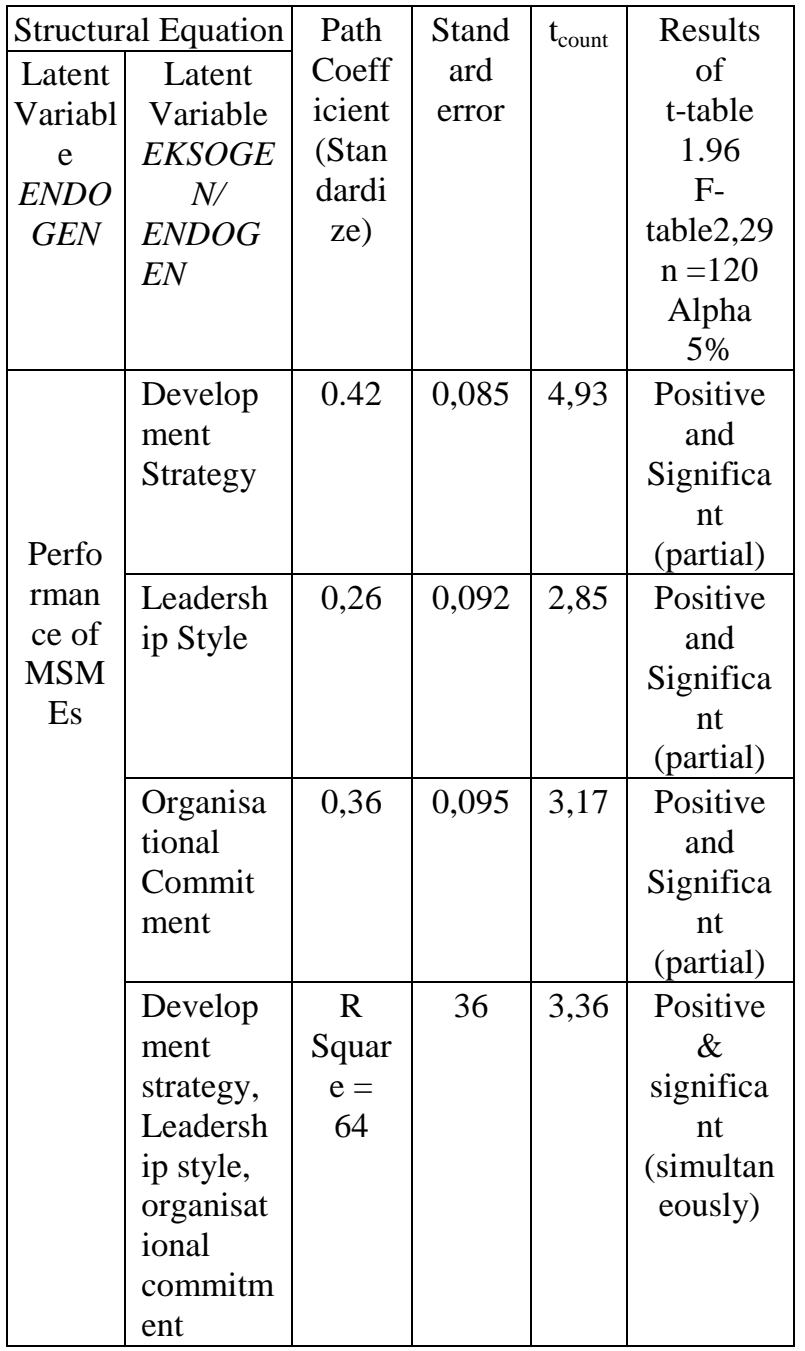

Table 2 and 3 are used as the reference in hypothesis testing. The criteria of the testing is as follows: $H_{0}$ is supported if $\mathrm{t}_{\text {count }}<1,96$ or $\mathrm{H}_{\mathrm{a}}$ is supported if $\mathrm{t}_{\text {count }}>1,96$. $\mathrm{H}_{\mathrm{a}}$ is also supported if $\mathrm{F}_{\text {count }}>\mathrm{F}_{\text {table }}$ and $\mathrm{H}_{\mathrm{o}}$ is supported if $\mathrm{F}_{\text {count }}<\mathrm{F}_{\text {table. }}$. In this study, 7 hypotheses are tested and the results found out that only on hypothesis that is not supported as presented in the table below.

Table 4 Result of Hypothesis Testing

\begin{tabular}{|c|c|c|}
\hline Hypothesis & Description & Conclusion \\
\hline $\mathrm{H} 1$ & $\begin{array}{c}\text { Development strategy } \\
\text { does not have any } \\
\text { effect on } \\
\text { organisational } \\
\text { commitment }\end{array}$ & $\begin{array}{c}\text { Hypothesis } \\
\text { is rejected }\end{array}$ \\
\hline $\mathrm{H} 2$ & $\begin{array}{c}\text { Leadership style has } \\
\text { an effect on } \\
\text { organisational } \\
\text { commitment }\end{array}$ & $\begin{array}{c}\text { Hypothesis } \\
\text { is accepted }\end{array}$ \\
\hline
\end{tabular}




\begin{tabular}{|c|c|c|}
\hline Hypothesis & Description & Conclusion \\
\hline H3 & $\begin{array}{c}\text { Development strategy } \\
\text { and leadership style } \\
\text { have an effect on } \\
\text { organisational } \\
\text { commitment }\end{array}$ & $\begin{array}{l}\text { Hypothesis } \\
\text { is accepted }\end{array}$ \\
\hline H4 & $\begin{array}{c}\text { Employee } \\
\text { commitment does not } \\
\text { have any effect on } \\
\text { MSMEs performance }\end{array}$ & $\begin{array}{l}\text { Hypothesis } \\
\text { is accepted }\end{array}$ \\
\hline H6 & $\begin{array}{c}\text { Leadership style has } \\
\text { an effect on MSMEs } \\
\text { performance }\end{array}$ & $\begin{array}{l}\text { Hypothesis } \\
\text { is accepted }\end{array}$ \\
\hline H7 & $\begin{array}{c}\text { Strategy development, } \\
\text { leadership style, } \\
\text { organisational } \\
\text { commitment have an } \\
\text { effect on MSMEs } \\
\text { performance }\end{array}$ & $\begin{array}{l}\text { Hypothesis } \\
\text { is accepted }\end{array}$ \\
\hline & $\begin{array}{c}\text { GGG has an effect on } \\
\text { employee performance }\end{array}$ & $\begin{array}{l}\text { Hypothesis } \\
\text { is accepted }\end{array}$ \\
\hline \multicolumn{3}{|c|}{} \\
\hline
\end{tabular}

\subsection{Direct and Indirect Analysis of Construct Variable}

This analysis is intended to see how strong the influence of a variable with other variables both directly and indirectly. The interpretation of these results will have important meanings in determining clear strategies in order to improve the performance of MSMEs. The results of direct and indirect effects are presented in the table below.

Table 5 Direct and Indirect Effect of Construct Variable

\begin{tabular}{|c|c|c|c|c|}
\hline No & $\begin{array}{c}\text { Effect of } \\
\text { exogenous } \\
\text { variable on } \\
\text { endogenous } \\
\text { variable }\end{array}$ & $\begin{array}{c}\text { Direc } \\
\mathbf{t}\end{array}$ & $\begin{array}{c}\text { Indirec } \\
\mathbf{t}\end{array}$ & Desc. \\
\hline 1 & $\begin{array}{c}\text { Effect of } \\
\text { development } \\
\text { strategy on } \\
\text { MSMEs } \\
\text { performance } \\
(0.26 \text { X } 0.26)\end{array}$ & $\begin{array}{c}0.067 \\
6\end{array}$ & & \\
\hline 2 & $\begin{array}{c}\text { Effect of } \\
\text { development } \\
\text { strategy on } \\
\text { MSMEs } \\
\text { performance } \\
\text { through } \\
\text { Organisational } \\
\text { commitment } \\
(0.17) \times(0.42)\end{array}$ & & 0.0714 & $\begin{array}{c}\text { unFull } \\
\text { Mediati } \\
n g\end{array}$ \\
\hline
\end{tabular}

\begin{tabular}{|c|c|c|c|}
\hline 3 & $\begin{array}{c}\text { Effect of } \\
\text { leadership style } \\
\text { on MSMEs } \\
\text { performance } \\
(0,30 \mathrm{X} 0,30) \\
\end{array}$ & 0.090 & \\
\hline 4 & $\begin{array}{c}\text { Effect of } \\
\text { leadership style } \\
\text { on MSMEs } \\
\text { performance } \\
\text { through } \\
\text { organisational } \\
\text { commitment } \\
(0.31) \times(0.42)\end{array}$ & & 0.1302 \\
\hline 5 & $\begin{array}{c}\text { Effect of } \\
\text { organisational } \\
\text { commitment on } \\
\text { MSMEs } \\
\text { performance } \\
(0.42 \times 0.42)\end{array}$ & $\begin{array}{c}0.176 \\
4\end{array}$ & \\
\hline
\end{tabular}

Notes: The effect of $\mathrm{X} 1$ does not have direct effect on $\mathrm{Y}$ and is insignificant. This shows that $\mathrm{Y}$ is imperfect intervening variable on the relation between $\mathrm{X} 1$ and $\mathrm{Z}$. Meanwhile, X2 is an intervening variable on MSMEs performance and has direct and indirect effect.

Dominant dimension and indicator for each variable are as follow:

- Development strategy (X1), dimension (1) entrepreneurship reinforcement, indicator education improvement $(\mathrm{X} 1.4=0.88)$

- Leadership style (X2), dimension (2) relationship orientation, indicator: cooperative relation $(\mathrm{X} 2.7=0,86)$

- Organizational commitment (Y), dimension affective, indicator: feeling as a part of the group (Y1.3=0,84)

- Organizational performance (Z), dimension capability (1), indicator: able to use available tools $(\mathrm{Z} 1 \cdot 17=0,86)$.

\subsection{Discussion}

When tested partially, development strategy has a positive effect on organizational commitment, although it is found to be insignificant. It indicates that the improvement of organizational commitment can be done through affective dimension with indicator of feeling a part of the group. Development strategy could also be increased through the reinforcement of entrepreneurship and education improvement. Furthermore, leadership style is positively and significantly affects organizational commitment meaning that the organizational commitment can be increased through affective dimension (indicator: feeling a part of the group) in which, is driven by leadership style through the dimension of relationship orientation (indicator: good relation)

Development strategy also has positive and significant effect on the performance of MSMEs. This shows that 
performance can be improved through capability dimension (indicator: able to use available devices), which is determined by strategy development through the reinforcement of entrepreneurship (indicator: education improvement). Furthermore, by increasing leadership style, the performance of MSMEs can also be increased through capability dimension, in which can be driven by leadership style using relationship orientation dimension (indicator: cooperative relationship). Performance can also be increased using organizational commitment through affective dimension with the indicator of feeling as a part of the group.

When tested simultaneously, both development strategy and leadership style have a positively significant effect on organizational commitment. This indicates that if development strategy and leadership style increased, it will increase organizational commitment in the dimension of affective (indicator: feeling a part of the group). Increasing development strategy and leadership style through each dimension, namely; entrepreneurship reinforcement (indicator: education improvement) and relationship orientation (indicator: cooperative relationship) can drive organizational commitment to increase.

Furthermore, it is also found that strategy development, leadership style and organizational commitment have positive and significant effect on the performance of MSMEs. Improving MSME performance can be prioritized through the dimensions of capability with the indicators of able to use available tools such as the use of e-commerce through online product marketing and so on. This can be done by directly increasing the development strategy in the dimensions of strengthening entrepreneurship such as addition of capital; increased business knowledge through increased education and training. The increase in MSMEs performance can also be supported by leadership style through the main dimensions of relationship orientation with indicators cooperation relationships (network) of input-supplier, raw materials (process into output) methods and the latest technology and ways of marketing quality products (output). Lastly, the performance also can be improved by increasing organizational commitment through looking for employees who are committed to the business that is being cultivated, including the commitment of entrepreneurs by increasing self-confidence that the business will be able to win the competition and be strong with the impact of future economic changes.

\section{CONCLUSION}

Based on the results, it can be concluded that there is no effect of the development strategy on organizational commitment, but it has a direct effect on the performance of MSMEs. Leadership style influences MSME performance directly or indirectly (in this case through organizational commitment). When tested simultaneously, the development strategy and leadership style affect the organizational commitment positively and significantly. Furthermore, the development strategy and leadership style and organizational commitment have a positive and significant effect on the performance of MSMEs.

For future research it is necessary to be able to replace intervening variables or other variables that are associated with organizational performance, such as work motivation variables, organizational commitment behavior in management science or organizational behavior. Moreover, for micro small and medium entrepreneurs it is necessary to increase entrepreneurship strengthening such as enhancing education and training to tie the capabilities of the use of available devices (marketing with ecommerce, online, increasing networks among fellow MSME entrepreneurs and making MSMEs an inseparable part of their lives.

\section{REFERENCES}

[1] Syahza. Almasdi \& Henny Indrawati, "Pemberdayaan Koperasi Berbasis Agribisnis di Daerah Pedesaan," Sosiohumaniora, Indonesia, Vol.12, No. 3, p. 207-220, 2010

[2] Kuncoro. M, "Strategi Bagaimana Meraih Keunggulan Kompetitif," Jakarta: Erlangga, 2005 p. 265

[3] David. F. R, "Manajemen Strategi; Konsep Edisi Ke-sepuluh,” Jakarta: Salemba Empat, 2006

[4] Sudaryanto. Ragimun, dan Rahma R, "Strategi pemberdayaan UMKM menghadapi pasar bebas ASEAN," Jember: Universitas Negeri Jember, 2011

[5] Afifuddin. 2010. Pengantar Administrasi Pembangunan.Bandung: CV Alfabeta.

[6] Hafsah. M. J. 2004. Upaya Pengembangan Usaha Mikro, Kecil dan Menengah (UMKM). Jurnal Infokop. Nomor 25 Tahun XX.

[7] Sedarmayanti, "Sumberdaya Manusia dan Produktifitas Kerja Edisi Revisi," Bandung: Mandarmaju, 2010 p.131

[8] Rivai. Veithzal, "Kepemimpinan dan Perilaku Organisasi” Jakarta: Rajawali Pers, 2010, p. 42

[9] Yukl. Gary A, "Managerial Leadership: A Review of Theory and Research," Journal of Management pp. 104,2010

[10] Chen. Li Yueh, "Examining the Effect of Organization Culture and Leadership Behavior on Organization Commitment, Job Satisfaction, and Job Performance at Small and Middle Sited Firm of Taiwan 
[11] Adeloka Uduclade, "Analisis Pengaruh Kompensasi, Pengembangan Karir dan Lingkungan Kerja dan Fisik Terhadap Komitmen Organisasi,” 2012

[12] Goutman James P. Environmente, "Analysis for Management," 2004

[13] Atmosoeprapto, "menuju SDM, Budaya dengan Kepemimpinan Efektif dan Manajemen Efisien," Jakarta: PT Elex Media Komputindo, 2012

[14] Meyer, J.P., \& Allen, N.J. Commitment in the Workplace: Theory, Research, and application. Thousand Oaks, CA: Sage Publications. 2007

[15] Sisdyani. Eka Andriani, "Pengaruh Pengalaman Kerja pada Kinerja Akademik Mahasiswa Fakultas Ekonomi Universitas Udayana," Buletin Studi Ekonomi 17(1), Bali: Universitas Udayana. 2012

[16] Utomo. Suardi, "Pegaruh Motivasi Kerja, Kepuasan Kerja, dan Komitmen Organisasi Terhadap Pegawai,'Jurnal Analisis Manajemen Vol. 5 No.1 pp. 75-86, Kudus. 2011

[17] Rahman, "Influence of Job Satisfaction to Organizational Citizenship Behavior among Senior High School Teacher in South Sulawesi," 2015

[18] Eka. Anantruna, Nur Mijayati, “Organizational Culture, Leadership Style, Influence Organization Commitment and performance of Teacher," International Journal of Business and Behavior Scientist Vol. 3 p.10, Malang. 2013

[19] Muji. Gunarto, Membangun Model Persamaan Struktural (SEM) dengan Program Lisrel, Palembang: IKAPI, Tunas Gemilang. Edisi Rivisi, 2015. 